

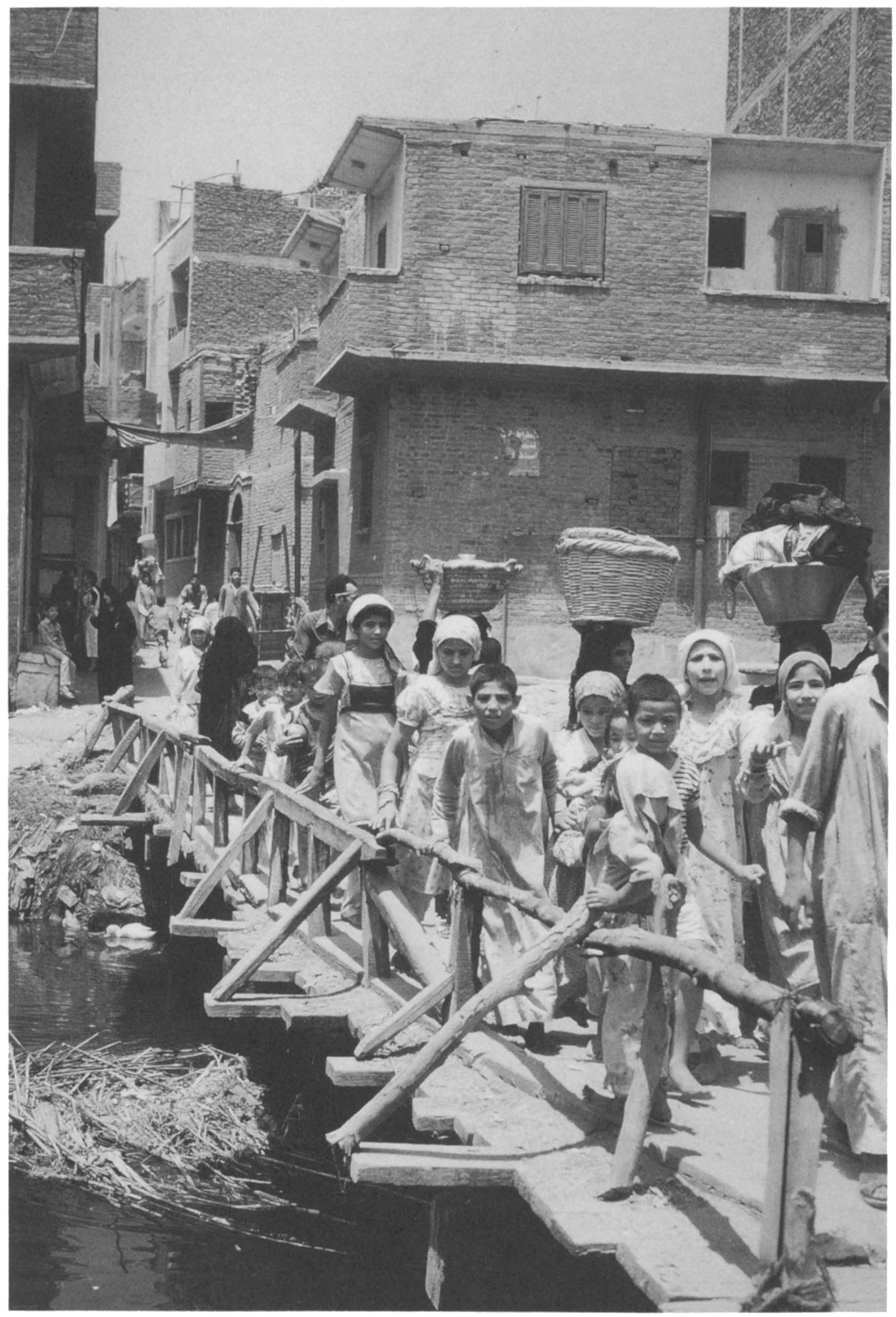

Children in the Delta village of Shanawan, Egypt

PHOTO BY HEATHER LOGAN TAYLOR 


\section{CHILDREN \\ IN THE MUSLIM \\ MIDDLE EAST}

EDITED BY ELIZABETH WARNOCK FERNEA

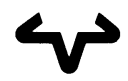

UNIVERSITY OF TEXAS PRESS

A UST IN 
Cover: Mother and two children outside mosque of Süleyman the Magnificent, Istanbul, Turkey. Photo by Heather Logan Taylor.

“The Small Lamp" by Ghassan Kanafani, translated by Tura Campanella Cook, copyright (C) I 995 by Fayez, Laila, and Anni Kanafani.

Copyright (C) I995 by the University of Texas Press

All rights reserved

Printed in the United States of America

First edition, 1995

Requests for permission to reproduce material from this work should be sent to

Permissions, University of Texas Press, Box 7819, Austin, TX 78713-7819.

\section{LIBRARY OF CONGRESS \\ CATALOGING-IN-PUBLICATION DATA}

Children in the Muslim Middle East / edited by Elizabeth Warnock

Fernea. - Ist ed.

p. $\quad \mathrm{cm}$.

Includes bibliographical references ( $\mathrm{p} . \quad$ ).

ISBN 0-292-7 I I 33 -6

ISBN 0-292-72490-X (pbk.)

I. Children-Middle East-Social conditions. 2. Child rearingReligious aspects-Islam. 3. Parenting-Religious aspects-Islam. 4. Islamic education-Middle East. I. Fernea, Elizabeth Warnock. HQ792.M628C45 I 995

$305.23^{\prime} 0956-\mathrm{dc} 20$

$94-46$ I 8 I

ISBN 978-0-292-76373-9 (library e-book)

ISBN 978-0-292-76374-6 (individual e-book) 